\title{
EFFICACY AND SAFETY OF HERBAL MEDICINES IN ASIA
}

\author{
Achmad Al Baihaqi ${ }^{\star}$, Jutti Levita ${ }^{2}$ \\ ${ }^{1}$ Undergraduate Program in Pharmacy, Faculty of Pharmacy, University of \\ Padjadjaran, Jatinangor Highway, Km 21, Jatinangor, Sumedang, West Java, \\ 45363, Indonesia \\ 2Department of Pharmacology and Clinical Pharmacy, Faculty of Pharmacy, \\ University of Padjadjaran, Jatinangor Highway, Km 21, Jatinangor, Sumedang, \\ West Java, 45363, Indonesia
}

*Corresponding author: Achmad Al Baihaqi (achmad18002@mail.unpad.ac.id)

| Received: 24 June 2021

\begin{tabular}{|c|}
\hline ARTICLE HISTORY \\
\hline Revised: 23 July 2021
\end{tabular}

|Accepted: 26 July 2021

\begin{abstract}
Herbal medicine $(\mathrm{HM})$ is a part of future alternative health care. According to the World Health Organization (WHO), almost $70-80 \%$ of the population of developing countries rely on $\mathrm{HM}$ as an immediate need for health services, one of which is the Asian region. With the high trend of a healthy lifestyle using natural ingredients, drug safety must be a significant concern. This review article aims to provide information on studying the toxicity of Asian herbal plants to hepatotoxic and nephrotoxic activities. The research method was conducted by searching using the keywords "Herbal Medicine(HM)," "Efficacy," "Nephrotoxicity," "Hepatotoxicity," "Asia," "extract" on the Google site and Google Scholar. The primary data sources used consisted of national journals, international journals, and the WHO website. Articles were screened using the inclusion criteria of Indonesian and English journals published in the last ten years. Of the toxicity study articles discussing 10 herbs-induced liver injury (HILI) and 10 drug-induced liver injury (DILI) that we reviewed, it is known that the dose consumed has a more significant effect on the incidence of hepatotoxicity and nephrotoxicity than the duration of administration with low doses. However, the period of administration with high doses has a significant relationship with liver and kidney damage. Therefore, disseminating safety studies to the public is very important to maximize drug efficacy and avoid hepatotoxicity and nephrotoxicity.
\end{abstract}

Keywords: herbal medicine (HM); hepatotoxicity; nephrotoxicity; Asia; safety

\section{Introduction}

Herbal medicine $(\mathrm{HM})$ is part of alternative health care in the future. ${ }^{1}$ According to the World Health Organization (WHO), $60 \%$ of the world's population depends on HM. Almost $70-80 \%$ of the people from developing countries rely on $\mathrm{HM}$ as an immediate need for health care. ${ }^{2}$ One of the continents with the most significant number of developing countries in Asia. ${ }^{3}$ Asian medicinal plants account for $50 \%$ of the export 
quantity and $45 \%$ of global revenue from traditional medicines. Two countries that play a significant role in this are China and India. ${ }^{4}$ Data from the Southeast Asian Institute of Thai-Chinese Medicine in 2010 showed that less than $1 \%$ of the population used acupuncture and $1-19 \%$ used Chinese HM. The absence of confidence in the side risks associated with synthetic drugs makes the use of $\mathrm{HM}$ much in demand ${ }^{5}$, mainly because of their secondary metabolite content. ${ }^{6}$

Secondary metabolites in plants have been shown to possess pharmacological activity to treat chronic and acute diseases, especially preventive therapy. ${ }^{7}$ With increasing healthy lifestyles using natural ingredients, drug safety should focus on attention apart from its efficacy effects. ${ }^{8}$ Safety is closely related to the quality control of HM. ${ }^{9}$ However, the limitations of scientific studies on evidence of efficacy and safety make HM still sceptical in the medical community. The lack of information regarding the safety of using HM in the general public is feared to be consumed more than the prescribed safe dose. This will be very dangerous considering the presence of nephrotoxic phytochemical compounds such as aristolochic acid and alkaloids. ${ }^{10,11}$ Paracelsus (Father of Toxicology) said in German, "Alle Dinge sind Gift und nichts ist ohne Gift, allein die Dosage machine, dass ein Ding kein Gift ist," which means "Everything is poison and nothing is without poison. Only the dose determines that something is non-toxic". ${ }^{12}$ Therefore, this review article systematically discusses the use of plant extracts in therapy and their dosage, the mechanism of nephrotoxicity, and hepatotoxicity by plant extracts, to increase awareness of the importance of dosage. ${ }^{13}$

\section{Methods}

The search was conducted using the keywords "Herbal Medicine," "Safety," "Nephrotoxicity," "Hepatotoxicity," "Asia," "extract" through the Google site and GoogleScholar. The primary data sources used consisted of national journals, international journals, and the WHO website. Articles were filtered with the inclusion criteria of accredited Indonesian and English journals focusing on hepatotoxic and nephrotoxic activity published in the last ten years.

\section{Results}

Table 1. Effect of Hepatotoxicity by Herbal Extracts

\begin{tabular}{|c|c|c|c|c|c|}
\hline No & Plant Names & Compound & Methods & $\begin{array}{c}\text { Hepatotoxic } \\
\text { Doses }\end{array}$ & Sources \\
\hline 1. & $\begin{array}{l}\text { "Dewa" } \\
\text { (Gynura } \\
\text { divaricata) } \\
\text { Leaf aqueous } \\
\text { extract }\end{array}$ & $\begin{array}{l}\text { Pyrrolizidine } \\
\text { alkaloid }\end{array}$ & $\begin{array}{l}\text { Acute toxicity } \\
\text { test (in Sprague } \\
\text { Dawley rats with } \\
\text { breast cancer). }\end{array}$ & $\begin{array}{l}\text { LD50 }=\geq 750 \\
\mathrm{mg} / \mathrm{kg} \text { BW p.o. } \\
\text { has been } \\
\text { observed } \\
\text { increases SGOT } \\
\text { and SGPT }\end{array}$ & 14 \\
\hline 2. & $\begin{array}{l}\text { "Gaharu" } \\
\text { (Aquilaria } \\
\text { malaccensis) } \\
\text { Leaf aqueous } \\
\text { extract }\end{array}$ & $\begin{array}{l}\text { terpenoids, } \\
\text { xanthonoids, } \\
\text { flavonoids, } \\
\text { benzophenon } \\
\text { es, } \\
\text { phytosterols, } \\
\text { phenolic }\end{array}$ & $\begin{array}{l}\text { Acute and sub- } \\
\text { acute toxicity } \\
\text { test (in Sprague- } \\
\text { Dawley (SD) } \\
\text { rats). }\end{array}$ & $\begin{array}{l}\text { - LD50 (acute } \\
\text { toxicity) = } \\
>2000 \mathrm{mg} / \mathrm{kg} \\
\text { p.o. has been } \\
\text { observed } \\
\text { increases }\end{array}$ & 15 \\
\hline
\end{tabular}




\begin{tabular}{ll}
\hline $\begin{array}{l}\text { acids,fatty } \\
\text { acid, 4'- } \\
\text { hydroxyaceta } \\
\text { nilide }\end{array}$ & ALP and \\
& ALT. \\
& LD50 (sub- \\
& acute \\
& toxicity) $=2000 \mathrm{mg} / \mathrm{kg}$ \\
& p.o. has been \\
& observed \\
lymphocytic \\
infiltration \\
and vascular \\
congestion.
\end{tabular}

\begin{tabular}{|c|c|c|c|c|c|}
\hline 3. & $\begin{array}{l}\text { Pulai bark } \\
\text { methanol } \\
\text { extract } \\
\text { (Alstonia } \\
\text { scholaris) }\end{array}$ & $\begin{array}{l}\text { Flavonoids, } \\
\text { tannins, } \\
\text { saponins, } \\
\text { alkaloids, } \\
\text { steroids, and } \\
\text { triterpenoids }\end{array}$ & $\begin{array}{lr}\text { Acute } & \text { and } \\
\text { subacute toxicity } \\
\text { tests } & \text { (in } \\
\text { Sprague- } & \\
\text { Dawley } & \text { (SD) } \\
\text { rats). } & \end{array}$ & 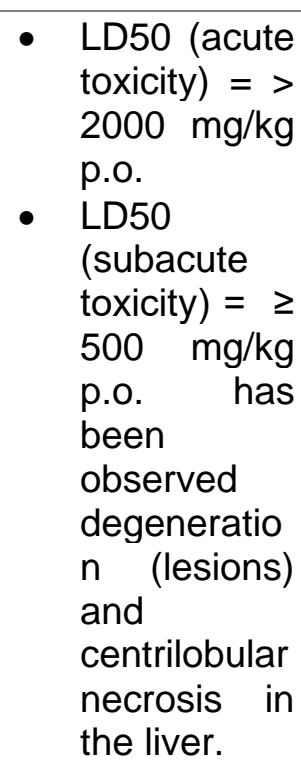 & 16,17 \\
\hline 4. & $\begin{array}{l}\text { Epigynous } \\
\text { auritum } \\
\text { ethanol } \\
\text { extract (EAE) }\end{array}$ & Glycosides & $\begin{array}{l}\text { Acute and } \\
\text { subacute toxicity } \\
\text { test (in mice) }\end{array}$ & $\begin{array}{l}\text { - LD50 (acute } \\
\text { toxicity) }=> \\
5000 \mathrm{mg} / \mathrm{kg} \\
\text { p.o. } \\
\text { LD50 } \\
\text { (subacute } \\
\text { toxicity) = } \geq \\
1250 \mathrm{mg} / \mathrm{kg} \\
\text { has been } \\
\text { observed } \\
\text { liver toxicity. }\end{array}$ & 18 \\
\hline 5. & $\begin{array}{l}\text { "Parang } \\
\text { Romang" } \\
\text { (Boehmeria } \\
\text { virgata (Forst) } \\
\text { leaf ethanolic } \\
\text { extract }\end{array}$ & Alkaloids & $\begin{array}{l}\text { Acute and } \\
\text { subacute toxicity } \\
\text { tests (in rats) }\end{array}$ & $\begin{array}{l}\text { LD50 (subacute } \\
\text { toxicity) = } \geq 250 \\
\mathrm{mg} / \mathrm{kg} \text { p.o. has } \\
\text { been observed } \\
\text { hydrophilic } \\
\text { degeneration of } \\
\text { liver cells. }\end{array}$ & 19 \\
\hline
\end{tabular}




\begin{tabular}{|c|c|c|c|c|c|}
\hline 6. & $\begin{array}{l}\text { Sipatah-patah } \\
\text { (Cissus } \\
\text { quadrangula } \\
\text { S.) stem } \\
\text { ethanol } \\
\text { extract }\end{array}$ & $\begin{array}{l}\text { Alkaloids, } \\
\text { tannins, } \\
\text { terpenoids, } \\
\text { flavonoids. }\end{array}$ & $\begin{array}{l}\text { Subacute } \\
\text { toxicity test (in } \\
\text { mice) }\end{array}$ & $\begin{array}{l}\text { LD50 = } \geq 105 \\
\mathrm{mg} / \mathrm{kg} \text { p.o. has } \\
\text { been observed } \\
\text { degeneration } \\
\text { and necrosis of } \\
\text { liver cells. }\end{array}$ & 20 \\
\hline 7. & $\begin{array}{l}\text { Bay leaf } \\
\text { (Syzygium } \\
\text { polyanthum } \\
\text { W.) ethanolic } \\
\text { extract }\end{array}$ & $\begin{array}{l}\text { Flavonoids, } \\
\text { alkaloids, } \\
\text { saponins, and } \\
\text { tannins }\end{array}$ & $\begin{array}{l}\text { Subchronic } \\
\text { toxicity test (in } \\
\text { Sprague- } \\
\text { Dawley rats) }\end{array}$ & $\begin{array}{l}\text { LD50 (in male } \\
\text { rats) = } \geq 1000 \\
\mathrm{mg} / \mathrm{kg} \text { p.o. has } \\
\text { been observed } \\
\text { histoarchitectura } \\
\text { defects in } \\
\text { hepatocytes. }\end{array}$ & 21 \\
\hline 8. & $\begin{array}{l}\text { Ketapang } \\
\text { (Terminalia } \\
\text { catappa) leaf } \\
\text { aqueous } \\
\text { extract }\end{array}$ & $\begin{array}{l}\text { Tannins, } \\
\text { triterpenoids, } \\
\text { flavonoids, } \\
\text { alkaloids, } \\
\text { steroids, } \\
\text { resins, and } \\
\text { saponins. }\end{array}$ & $\begin{array}{l}\text { Subchronic } \\
\text { toxicity test (in } \\
\text { mice) }\end{array}$ & $\begin{array}{l}\text { LD50 = } \geq 125 \\
\mathrm{mg} / \mathrm{kg} \text { p.o. has } \\
\text { been observed } \\
\text { increased cell } \\
\text { swelling and } \\
\text { necrosis with } \\
\text { increasing dose. }\end{array}$ & 22 \\
\hline 9. & $\begin{array}{l}\text { Pericampylus } \\
\text { glaucus L. leaf } \\
\text { ethanol } \\
\text { extract }\end{array}$ & Alkaloids & $\begin{array}{l}\text { Acute and } \\
\text { subacute toxicity } \\
\text { tests (in mice) }\end{array}$ & 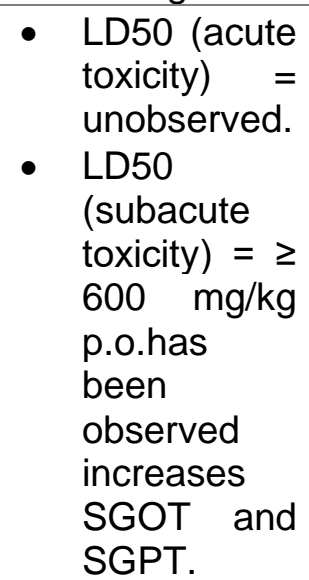 & 23 \\
\hline 10. & $\begin{array}{l}\text { Retama } \\
\text { raetam (RR) } \\
\text { fruit methanol } \\
\text { extract }\end{array}$ & $\begin{array}{l}\text { Flavones, } \\
\text { quinolizidine } \\
\text { alkaloids, } \\
\text { piperidine } \\
\text { alkaloids, } \\
\text { lupin } \\
\text { alkaloids, } \\
\text { polysaccharid } \\
\text { es, and } \\
\text { essential oils }\end{array}$ & $\begin{array}{l}\text { Acute and } \\
\text { subacute toxicity } \\
\text { tests. }\end{array}$ & $\begin{array}{l}\text { - } \text { LD50 (acute } \\
\text { toxicity) = } \\
1995 \mathrm{mg} / \mathrm{kg} \\
\text { p.o. } \\
\text { LD50 } \\
\text { (subacute } \\
\text { toxicity) = } \geq \\
500 \quad \mathrm{mg} / \mathrm{kg} \\
\text { p.o. has } \\
\text { been } \\
\text { observed } \\
\text { degeneratio } \\
\mathrm{n} \\
\text { hepatocyte. }\end{array}$ & 24 \\
\hline
\end{tabular}


Table 2. Effect of Nephrotoxicity by Herbal Extracts

\begin{tabular}{|c|c|c|c|c|c|}
\hline No. & Plant Name & Compound & Methods & $\begin{array}{l}\text { Nephrotoxic } \\
\text { Doses }\end{array}$ & Sources \\
\hline 1. & $\begin{array}{l}\text { Calpoureh } \\
\text { (Teucrium } \\
\text { polium L.) } \\
\text { ethanol } \\
\text { extract }\end{array}$ & $\begin{array}{l}\text { Salvigenin, } \\
\text { cirsiliol, } \alpha \text { - and } \beta \text { - } \\
\text { pinen, sabinene, } \\
\text { myrcene, } \\
\text { germacrene D, } \\
\text { limonene, } \beta \text { - } \\
\text { caryophyllene, } \\
\text { and spathulenol. }\end{array}$ & \begin{tabular}{l}
\multicolumn{2}{l}{ Subchronic } \\
toxicity test. \\
(in Wistar \\
rats)
\end{tabular} & $\begin{array}{l}\text { LD50 = } \geq 50 \\
\mathrm{mg} / \mathrm{kg} \text { i.p. has } \\
\text { been observed } \\
\text { that } 28 \text { days } \\
\text { after } \\
\text { injection the } \\
\begin{array}{l}\text { stopped, there } \\
\text { was kidney } \\
\text { damage }\end{array}\end{array}$ & 25 \\
\hline
\end{tabular}

\begin{tabular}{|c|c|c|c|c|c|}
\hline 2. & $\begin{array}{l}\text { Mahogany } \\
\text { Seed } \\
\text { (Swietenia } \\
\text { mahagoni } \\
\text { Jacq.) } \\
\text { ethanol } \\
\text { extract }\end{array}$ & Triterpenoids & \begin{tabular}{l}
\multicolumn{2}{l}{ Subchronic } \\
toxicity test. \\
(in Wistar \\
rats)
\end{tabular} & $\begin{array}{lr}\text { LD50 } \geq & 50,96 \\
\text { mg/200g } & \text { p.o. } \\
\text { has } & \text { been } \\
\text { observed } & \\
\text { increases } & \\
\text { creatinine } & \text { and } \\
\text { urea } & \\
\end{array}$ & 26 \\
\hline 3. & $\begin{array}{l}\text { Stachys } \\
\text { lavandulifoli } \\
\text { a ethanol } \\
\text { extract }\end{array}$ & $\begin{array}{l}\text { Phenylpropanoi } \\
\text { ds, } \\
\text { Germacrene-D, } \\
\beta \text {-phellandrene, } \\
\beta \text {-pinene, } \\
\text { myrcene dan } \alpha \text { - } \\
\text { pinene }\end{array}$ & \begin{tabular}{l}
\multicolumn{2}{l}{ Subchronic } \\
toxicity test. \\
(In Wistar \\
rats)
\end{tabular} & 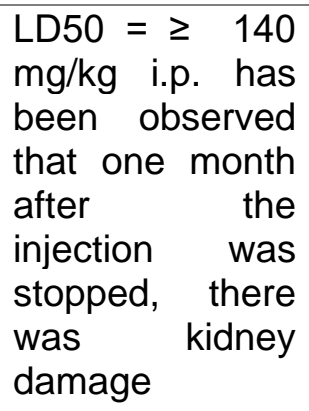 & 27 \\
\hline 4. & $\begin{array}{l}\text { Leaf of } \\
\text { Karamuntin } \\
\text { g } \\
\text { (Rhodomyrt } \\
\text { us } \\
\text { tomentosa, } \\
\text { H.) ethanol } \\
\text { extract. }\end{array}$ & Saponin & $\begin{array}{l}\text { Acute toxicity } \\
\text { test: pretest } \\
\text { and posttest } \\
\text { control group } \\
\text { design. (in } \\
\text { rats) }\end{array}$ & $\begin{array}{l}\text { LD50 }=\geq 600 \\
\mathrm{mg} / \mathrm{kg} \text { BW has } \\
\text { been observed } \\
\text { to increase } \\
\text { creatinine and } \\
\text { urea }\end{array}$ & 28 \\
\hline 5. & $\begin{array}{l}\text { Aristolochia } \\
\text { longa L. } \\
\text { aqueous } \\
\text { extract. }\end{array}$ & Aristolochic Acid & $\begin{array}{l}\text { Acute and } \\
\text { subchronic } \\
\text { toxicity tests. } \\
\text { (in Swiss } \\
\text { albino rats) }\end{array}$ & $\begin{array}{l}\text { LD50 } \\
\text { (subchronic } \\
\text { toxicity) = } \geq 2,5 \\
\text { g/kg p.o. has } \\
\text { been observed } \\
\text { for three weeks } \\
\text { showed mild } \\
\text { tubular atrophy; } \\
\text { for six weeks, } \\
\text { tubular necrosis } \\
\text { occurred. }\end{array}$ & 29 \\
\hline
\end{tabular}




\begin{tabular}{|c|c|c|c|c|c|}
\hline 6. & $\begin{array}{l}\text { Cinnamon } \\
\text { (Cinnamom } \\
\text { um cassia) } \\
\text { extract }\end{array}$ & Coumarin & $\begin{array}{l}\text { Acute, } \\
\text { subchronic, } \\
\text { and } \\
\text { genotoxicity } \\
\text { test. (in F344 } \\
\text { mice) }\end{array}$ & $\begin{array}{l}\text { LD50 = } 22000 \\
\mathrm{mg} / \mathrm{kg} \text { p.o. It } \\
\text { has } \\
\text { observed been } \\
\text { induce } \\
\text { increase } \\
\text { kidney weight. }\end{array}$ & 30 \\
\hline 7. & $\begin{array}{l}\text { Ma } \\
\text { huang/Ephe } \\
\text { dra Herba } \\
\text { (Ephedra } \\
\text { sinica } \\
\text { Stapf.) } \\
\text { aqueous } \\
\text { extract }\end{array}$ & $\begin{array}{l}\text { Ephedrine and } \\
\text { pseudoephedrin } \\
\text { e }\end{array}$ & \begin{tabular}{l}
\multicolumn{2}{l}{ Subchronic } \\
toxicity \\
(in test. \\
mice).
\end{tabular} & $\begin{array}{l}\text { LD } 50=\geq 1000 \\
\mathrm{mg} / \mathrm{kg} \text { p.o. has } \\
\text { been observed } \\
\text { to increase the } \\
\text { incidence and } \\
\text { severity of } \\
\text { tubular } \\
\text { basophilia. }\end{array}$ & 31 \\
\hline 8. & $\begin{array}{l}\text { Houttuynia } \\
\text { cordata } \\
\text { ethanol } \\
\text { extract }\end{array}$ & $\begin{array}{l}\beta \text {-myrcene and } \\
2 \text { - undecanone }\end{array}$ & $\begin{array}{l}\text { Acute and } \\
\text { sub-acute } \\
\text { toxicity tests. } \\
\text { (in Sprague } \\
\text { Dawley rats) }\end{array}$ & $\begin{array}{l}\text { LD50 (acute } \\
\text { toxicity) => } \\
2000 \mathrm{mg} / \mathrm{kg} \\
\text { p.o. } \\
\text { LD50 } \\
\text { (Subacute } \\
\text { toxicity) }=\geq \\
500 \mathrm{mg} / \mathrm{kg} \\
\text { p.o. has } \\
\text { been } \\
\text { observed to } \\
\text { exhibit renal } \\
\text { toxicity. }\end{array}$ & 32,33 \\
\hline 9 & $\begin{array}{l}\text { Garlic } \\
\text { (Allium } \\
\text { sativum) } \\
\text { ethanol } \\
\text { extract }\end{array}$ & Glycosides & $\begin{array}{l}\text { Subchronic } \\
\text { toxicity test. } \\
\text { (in Wistar } \\
\text { rats) }\end{array}$ & $\begin{array}{l}\text { LD50 }=\geq 400 \\
\text { mg/kg p.o. has } \\
\text { been observed } \\
\text { degeneration of } \\
\text { tubular epithelial } \\
\text { cells lining } \\
\text { Bowman's } \\
\text { capsule, tubular } \\
\text { dilatation, and } \\
\text { enlargement of } \\
\text { Bowman's } \\
\text { space. }\end{array}$ & 34 \\
\hline 10. & $\begin{array}{l}\text { Balm } \\
\text { (Melissa } \\
\text { officinalis } \\
\text { L.) hydro- } \\
\text { alcoholic } \\
\text { extract }\end{array}$ & $\begin{array}{l}\text { Eugenol } \\
\text { glucoside,rosma } \\
\text { rinic acid, } \\
\text { cynaroside,cos } \\
\text { mosin,rhamnocit } \\
\text { rin,isoquercitrin, } \\
\text { carnosic acid, } \\
\text { ursolic, and } \\
\text { oleanolic }\end{array}$ & $\begin{array}{l}\text { Subchronic } \\
\text { toxicity test. }\end{array}$ & $\begin{array}{l}\text { LD50 = } \geq 1200 \\
\mathrm{mg} / \mathrm{kg} \quad \text { p.o. } \\
\text { Prominent } \\
\text { lesions, tubular } \\
\text { necrosis, } \\
\text { glomerular } \\
\text { atrophy, and } \\
\text { congestion have } \\
\text { been observed. }\end{array}$ & 35 \\
\hline
\end{tabular}




\section{Discussion}

\section{Prevalence of Herbal Medicines Use in Asia}

The use of HM in Asia and Indonesia is estimated to increase over the years. In some Asian and African countries, about $80 \%$ of the rural population depends on traditional medicine for primary health care ${ }^{36}$ China and India are the Asian countries that play the most role in the development of HM. India has played an essential part for thousands of years in managing medicinal plants as alternative therapies. ${ }^{37}$ In 2016, a study in 32 primarily high-income countries stated that the prevalence rate of traditional therapy use over the past 12 months averaged 26.4\%, ranging from less than 10\% in some Eastern European countries to more than $50 \%$ in China, South Korea, and the Philippines. ${ }^{38}$ In ASEAN, the highest use of herbal therapy was in Malaysia (55.6\%), Singapore (among older adults) (42.7\%), the Philippines (6.3\%), Cambodia (5.4\%), Vietnam (3.5\%), Thailand (2.6\%) and Indonesia (2.0\%). ${ }^{39}$ In Indonesia, based on an extensive national household survey in $2013,30.4 \%$ of families used traditional medicine for health care. ${ }^{40}$ The current use of conventional medicine is generally only found in patients with cancer or malignant tumors (14.4\%), followed by arthritis/rheumatism $(11.3 \%)$, high cholesterol $(11.3 \%)$, stroke $(10.2 \%)$, diabetes $(9.9 \%)$, kidney disease $(9.7 \%)$, liver disease $(8.0 \%)$, hypertension (7.2\%), and memory-related diseases (6.8\%). ${ }^{41}$

\section{Mechanism of Hepatotoxicity}

The liver is part of the human organ that is very sensitive to injury due to its vital role in neutralizing toxins. ${ }^{42}$ Therefore, excessive exposure to toxins from food, beverages, drugs (synthetic and non-synthetic $(\mathrm{HM})$ ) has the potential to cause liver injury (hepatotoxicity). ${ }^{43}$ Hepatotoxicity induced by irregular drug use is commonly known as DILI (Drug-Induced Liver Injury). ${ }^{44}$ Hepatotoxicity due to HM is commonly known as HILI (Herb-Induced Liver Injury). ${ }^{45}$

$\mathrm{HILI}$ is liver damage which is one of the causes is triggered by the use of plants with unknown toxicity limits. ${ }^{46}$ The mechanism of HILI is divided into three stages, starting from early liver cell damage through direct cell stress, mitochondrial suppression, and/or specific immune response. Following the mitochondrial permeability transition (MPT) stage, early injury can induce MPT, and cellular stress directly induces MPT via internal pathways. The last stage is hepatocyte death; MPT can cause necrosis or apoptosis depending on ATP defense availability, and regeneration abilities can restore the damaged liver cells. Any action taken involves various environmental and genetic factors, and the degree of liver damage varies. ${ }^{47}$

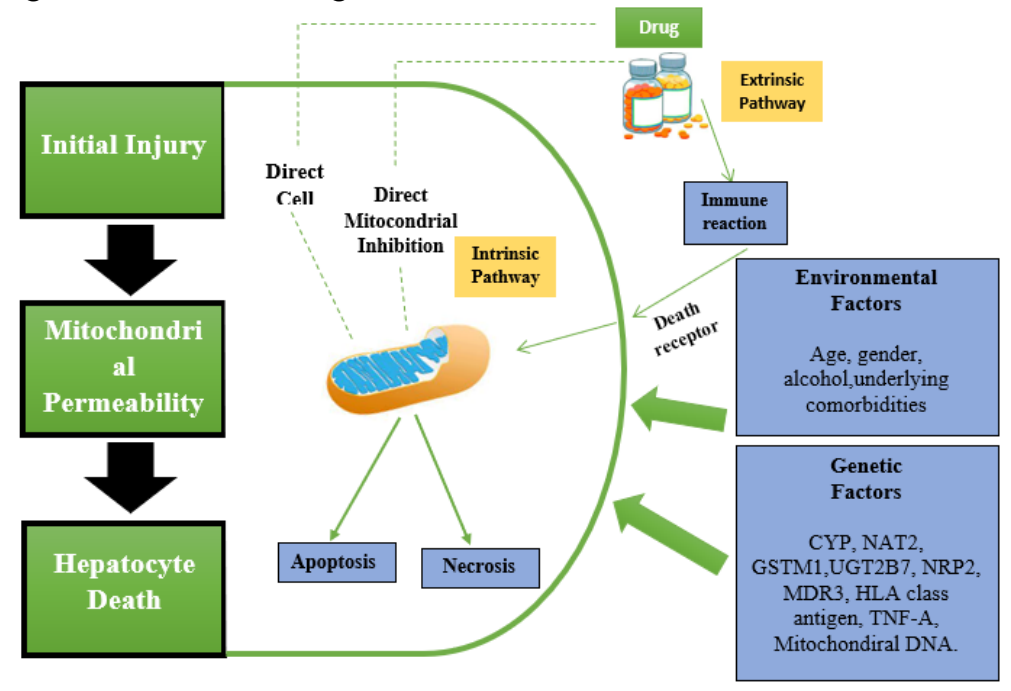

Figure 1. Mechanism of Drug-Induced Liver Injury ${ }^{48}$ 
The level of hepatotoxicity caused by HILI is classified into three types, including hepatocellular, cholestatic, and mixed. ${ }^{45}$ These were classified according to the value of the $R$ ratio obtained by comparing the results of the initial measurement of alanine aminotransferase (ALT) with alkaline phosphatase (ALP) using multiples of the upper limit of the normal range for both values. $R \geq 5$ indicates hepatocellular liver injury; $R \leq 2$ is cholestatic; and $2<\mathrm{R}<5$ is mixed. ${ }^{49,50}$ There are two critical factors for HILI development, including the level of drug exposure (dose) and the adaptive immune response. Drug exposure and the nature of the drug administered play a significant role in the early stages of cell damage. Once damaged, both innate and adaptive responses emerge and play an essential role in triggering inflammation and tissue injury. ${ }^{47}$

\section{Mechanism of Nephrotoxicity}

Kidneys are part of the functional unit of the body, containing about 1 million nephrons, one of which functions play an essential role in neutralizing drug toxicity. The loss of one or more cells in the nephron can cause functional kidney damage. ${ }^{51}$ The term nephron damage due to exogenous drugs/toxins is known as nephrotoxicity. ${ }^{52}$

Nephrotoxicity has a relationship with the use of HM. The use of HM that has been shown to cause nephrotoxicity directs their toxic effects through one or more pathogenic mechanisms. ${ }^{53}$ There are different mechanisms of nephrotoxicity, including renal tubular toxicity, inflammation, glomerular damage, crystal nephropathy, and thrombotic microangiopathy. Toxic substances and drugs induce oxidative stress that causes damage to the renal tubules, thereby causing potential damage to the renal tubular transport system. ${ }^{54}$ This oxidative stress arises due to the presence of lipopolysaccharide (LPS), which activates NF-B and mitogen-activated protein kinases (MAPKs). ${ }^{55}$

One well-known example of nephrotoxicity due to $\mathrm{HM}$ is triggered by aristolochic acid. ${ }^{56}$ Aristolochic acid (AA) is a group of nitrophenanthrene carboxylic acid compounds found in the Aristolochiaceae plant family, consisting of aristolochic acid I (AAI) and aristolochic acid II (AAII), which are distinguished by the presence of an O-methoxy group at position 8 for AAI while AAll does not have an O-methoxy group at position 8 (indicated by a bold arrow in Figure 2). ${ }^{57}$<smiles>CCOc1cccc2c1cc([N+](=O)[O-])c1c(C(=O)O)cc3c(c12)OCO3</smiles><smiles>O=C(O)c1cc2c(c3c1c([N+](=O)[O-])cc1ccccc13)OCO2</smiles>

Figure 2. Chemical Structure of AAI (left) and AAll (right) ${ }^{58}$

Based on research, AA has been associated with the induction of oxidative stress (ROS) and apoptosis. ${ }^{59}$ Exposure to AAI in the proximal renal tubule that enters through OAT1/OAT3(organic anion transporter 1/organic anion transporter 3) induces ROS that can cause DNA damage (TP53, OGG1), induce ER(endoplasmic reticulum) and mitochondrial stress, or activate the MAPK(mitogen-activated protein kinase) pathway. ${ }^{60}$ ER induction causes an increase in $\mathrm{Ca}^{2+}$, which causes the mitochondria to release cytochrome $\mathrm{C}$ (Cyt C). Cyt $\mathrm{C}$ activates caspase-3, resulting in apoptosis. Endoplasmic reticulum (ER) and $A A I$-induced mitochondrial stress were also associated with increased protein complexes (elF2a, CHOP, GRP78) that could induce cell apoptosis. 
As for the interaction of AAI with MAPK, the induction of apoptosis is related to the activation of p38 or p53 (as demonstrated in Figure 3). ${ }^{57}$

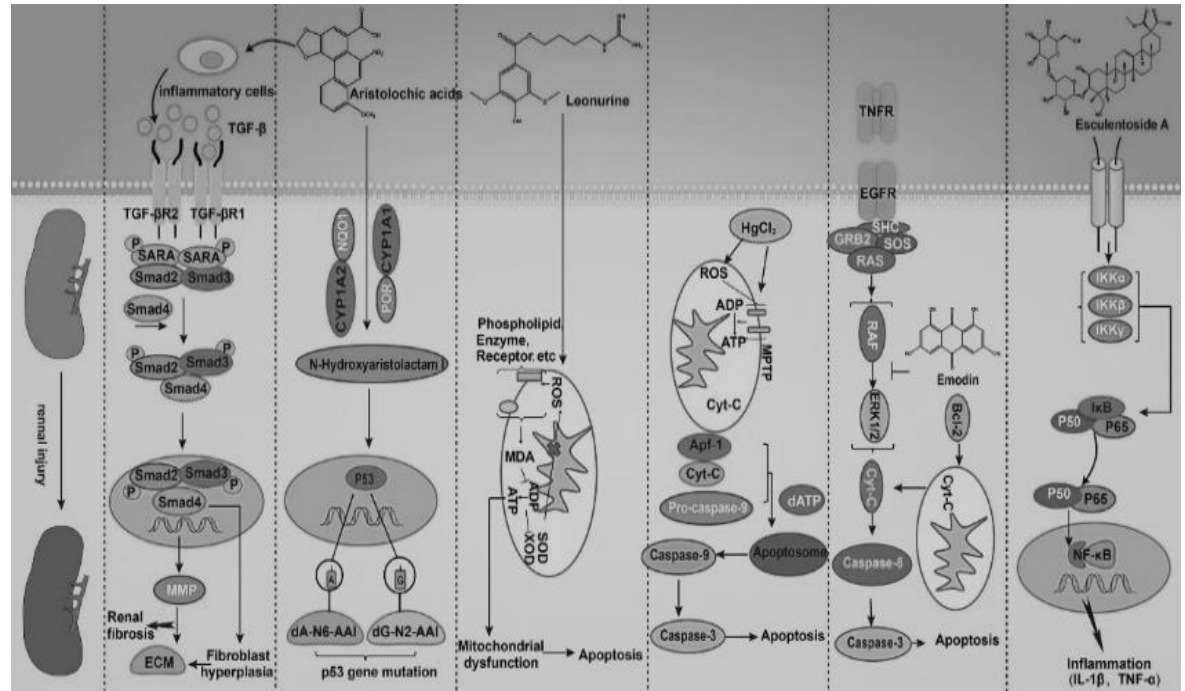

Figure 3. Mechanism of Herb Induced Kidney Injury 61

ROS(reactive oxygen species); CYP1A1(cytochrome P450 family 1 subfamily A member 1 ); CYP1A2(cytochrome P450 family 1 subfamily A member 2); MAPK(mitogen-activated protein kinase); Cyt C(cytochrome C); SARA(smad anchor for receptor activation); TGF$\beta R 1 / T G F-\beta R 2$ (transforming growth factor-beta receptor $1 /$ transforming growth factor-beta receptor 2); $\quad E C M($ extracellular matrix); $M M P($ matrix metalloproteinase); MDA(Malondialdehyde); TNFR(tumor necrosis factor receptors); EGFR(epidermal growth factor receptor); ERK1/2(extracellular signal regulated kinase 1/2); Bcl-2(B-cell lymphoma 2); ATP (adenosine tri-phosphate); ADP(adenosine diphosphate); SOS(son of sevenless); $\mathrm{SHC}$ (src homology and containing protein); GRB2 (growth factor receptor-bound protein 2).

\section{Hepatotoxic and Nephrotoxic-Inducing Herbs}

Hepatotoxicity is a severe event of the liver that may cause death if not adequately controlled. SGOT, SGPT, and histopathological tests can identify hepatotoxicity. ${ }^{62}$ Hepatotoxicity can occur due to accidental contamination with non-herbal drugs causing hepatotoxicity (e.g., NSAIDs) or the content of secondary metabolites of some HM. ${ }^{63,64}$ Sometimes, hepatotoxicity is also associated with self-medication without medical assistance, misdiagnosis, and the presence of comorbid diseases. ${ }^{65-67}$ The lack of information regarding HM toxicity studies may also contribute to hepatotoxicity. ${ }^{68} \mathrm{HM}$ consists of unrefined plant parts or plant extracts containing several elements that are generally considered to work synergistically. ${ }^{69}$ The following are examples of several plant toxicity studies on hepatotoxicity shown in Table 1.

Likewise, nephrotoxicity, as well as hepatotoxicity, has a relationship with HM. Several herbal plants used in the long term, from the results of toxicity studies, have been observed to induce tubular necrosis and atrophy. ${ }^{29}$ Urea and creatinine levels can also observe the glomerular function. However, the histopathological test remains the golden standard in identifying nephrotoxicity. ${ }^{70}$ The following are some examples of plant toxicity studies on nephrotoxicity shown in Table. 2.

Of some of the articles that we have reviewed, it is not entirely safe to use herbal remedies. Several herbal plants have hepatotoxicity and nephrotoxicity activity. It is known that increasing the dose consumed more affects the incidence of hepatotoxicity and nephrotoxicity than the duration of administration with low doses. However, prolonged exposure will significantly affect liver and kidney damage if high doses are 
used. Therefore, it is crucial to know the toxic dose of HM use and further research to avoid lethal hepatotoxic and nephrotoxic. ${ }^{71,72}$

\section{Conclusion}

The use of HM is closely related to the dose. Of the results of toxicity studies of several plants, it was observed that there was cell degeneration activity that worsened the functional conditions of the liver and kidneys with increasing doses. Therefore, disseminating information regarding safety studies to the public is very important to maximize drug efficacy and avoid lethal hepatotoxicity and nephrotoxicity.

\section{Acknowledgments}

The authors thank the Rector of Universitas Padjadjaran for funding the publication fee of this article via the Universitas Padjadjaran Academic-Leadership grant of Prof. Dr. Dra. Jutti Levita, M.Si., Apt. batch 2021.

\section{References}

1. Silveira D, Prieto JM, Freitas MM, Mazzari ALDA. Herbal medicine and public healthcare: Current and future challenges. In: Natural Products as Source of Molecules with Therapeutic Potential: Research and Development, Challenges and Perspectives. Springer International Publishing; 2018. p. 495-515.

2. Kanjanahattakij N, Kwankhao P, Vathesatogkit P, Thongmung N, Gleebbua Y. Herbal or traditional medicine consumption in a Thai worker population : pattern of use and therapeutic control in chronic diseases. 2019;1-9.

3. UN. Economic and Social Survey of Asia and The Pacific 2020. Towards Sustainable Economies. 2020.

4. Astutik S, Pretzsch J, Kimengsi JN. Asian medicinal plants' production and utilization potentials: A review. Vol. 11, Sustainability (Switzerland). 2019. p. 133.

5. Who global report on traditional and complementary medicine 2019. 2019.

6. Seca AML, Pinto DCGA. Biological Potential and Medical Use of Secondary Metabolites. Medicines. 2019;6(2):66.

7. Ahmad Khan MS, Ahmad I. Herbal Medicine: Current Trends and Future Prospects. New Look to Phytomedicine: Advancements in Herbal Products as Novel Drug Leads. Elsevier Inc.; 2018. 3-13. Available from: http://dx.doi.org/10.1016/B978-0-12-814619-4.00001-X

8. Yang Y. Use of herbal drugs to treat COVID-19 should be with caution. The Lancet. 2020;395(10238):1689-90. Available from: http://dx.doi.org/10.1016/S0140-6736(20)31143-0

9. Mithun Rudrapal D, Chetia. Herbal Drugs: Efficacy, Toxicity, and Safety Issues. Evidence Based Validation of Traditional Medicines. 2021;537-53. Available from: https://link.springer.com/chapter/10.1007/978-981-15-8127-4_26

10. Lv W, Piao JH, Jiang JG. Typical toxic components in traditional Chinese medicine. Expert Opinion on Drug Safety. 2012;11(6):985-1002.

11. $\mathrm{Xu} \mathrm{XL}$, Yang LJ, Jiang JG. Renal toxic ingredients and their toxicology from traditional Chinese medicine. Expert Opinion on Drug Metabolism and Toxicology. 2016;12(2):149-59.

12. Tsatsakis AM, Vassilopoulou L, Kovatsi L, Tsitsimpikou C, Karamanou M, Leon $G$, et al. The dose response principle from philosophy to modern toxicology: The 
impact of ancient philosophy and medicine in modern toxicology science. Toxicology Reports. 2018:1107-13. Available from: https://doi.org/10.1016/j.toxrep.2018.10.001

13. Sethi G. Multifaceted role of gamma tocotrienol in cancer therapy. Journal of Clinical Trials. 2018;08:4172.

14. Christina I, Setyawati An, Dk Kt. Pengaruh Ekstrak Daun Dewa (Gynura Divaricata) Terhadap Kadar Sgot Dan Sgpt (Studi Eksperimental Pada Tikus Sprague Dawley Betina Model Kanker Payudara). Diponegoro Medical Journal (Jurnal Kedokteran Diponegoro) . 2016;5(4):1013-25. Available from: https://ejournal3.undip.ac.id/index.php/medico/article/view/14476

15. Razak RNHA, Rahman SA, Hamdan AH, Ramli R, Isa MLM, Muhammad $H$, et al. Evaluation of acute and sub-acute oral toxicity of the aqueous extract of aquilaria malaccensis leaves in Sprague Dawley rats. Asia-Pacific Journal of Molecular Biology and Biotechnology. 2019;27(1):20-32.

16. Bello I, Suliman Bakkouri A, Tabana YM, Al-Hindi B, Al-Mansoub A, Mahmud R, et al. medical sciences Acute and Sub-Acute Toxicity Evaluation of the Methanolic Extract of Alstonia scholaris Stem Bark. 2016; Available from: www.mdpi.com/journal/medsci

17. Zuraida. Phytocemical compounds of different species of Alstonia sp. from Palembang- South Sumatera. IOP Conference Series: Earth and Environmental Science. 2019;308(1).

18. Yang M, Wu Z, Wang Y, Kai G, Singor Njateng GS, Cai S, et al. Acute and subacute toxicity evaluation of ethanol extract from aerial parts of Epigynum auritum in mice. Food and Chemical Toxicology. 2019 Sep 1;131:110534.

19. Intan Aek, Manggau Ma, Cangara H. Studi Histopatologi Organ Hati Dan Ginjal Dari Tikus Putih (Rattus Novergicus) Setelah Pemberian Dosis Tunggal Dan Berulang Ekstrak Etanol Parang Romang (Boehmeria Virgata (Forst) Guill). Majalah Farmasi Dan Farmakologi. 2018;22(2):64-8. Available From: Http://Journal.Unhas.Ac.Id

20. Sari W, Fitri S, Ceriana R, Sunarti S. Efek Toksik Pemberian Ekstrak Batang Sipatah-patah (Cissus quadrangula Salisb.) Terhadap Gambaran Histologi Hati dan Ginjal Mencit. Jurnal Bioleuser. 2017;1(1). Available from: http://erepository.unsyiah.ac.id/bioleuser/article/view/8304

21. Dewijanti I, Mangunwardoyo W, Astari Dwiranti, Muhammad Hanafi, Nina Artanti. Short Communication: Effects Of The Various Source Areas Of Indonesian Bay Leaves (Syzygium Polyanthum) On Chemical Content And Antidiabetic Activity. Biodiversitas Journal Of Biological Diversity. 2020;21(3):1190-5.

22. Nugroho RA, Cening N, Puspa S, Aryani R, Rudianto WP, Manurung $\mathrm{H}$. Subchronic Toxicity Test of Indian Almond ( Terminalia catappa ) Leaves Water Extract on The Liver Histology of Mice (Mus musculus ). 2020;4(2):177-82.

23. Kifayatullah M, Mustafa MohdS, Sengupta P, Sarker MdMR, Das A, Das SK. Evaluation of the acute and sub-acute toxicity of the ethanolic extract of Pericampylus glaucus (Lam.) Merr. in BALB/c mice. Journal of Acute Disease. 2015;4(4):309-15.

24. Algandaby MM. Assessment of acute and subacute toxic effects of the Saudi folk herb Retama raetam in rats. Journal of the Chinese Medical Association. 2015;78(12):691-701.

25. Nasri H, Rafieian-Kopaei M. Nephrotoxicity of hydroalcoholic extract of teucrium polium in wistar rats. Journal of Isfahan Medical School. 2014;32(290):938-46.

26. Rasyad A, Mahendra P, Hamdani Y. Uji Nefrotoksik dari Ekstrak Etanol Biji Mahoni (Swietenia Mahagoni Jacq.) terhadap Tikus Putih Jantan Galur Wistar. Jurnal Penelitian Sains. 2012;15(2):168083. 
27. Taghikhani M, Nasri $H$, Asgari A, Afrough $H$, Namjoo AR, Ansari-Samani R, et al. The renal toxicity of hydroalcoholic extract of stachys lavandulifolia Vahl in Wistar rats. Life Science Journal. 2012;9(4):3025-31.

28. Dv PLX, Trianto HF, Fitrianingrum I. Efek Nefrotoksik Pemberian Ekstrak Etanol 70 \% Daun Karamunting ( Rhodomyrtus tomentosa ( Aiton ) Hassk .) terhadap Kadar Ureum dan Kreatinin Serum Tikus Galur Wistar. 2015;293-305.

29. Benzakour G, Benkirane N, Amrani M, Oudghiri M. Immunostimulatory potential of Aristolochia longa $L$. induced toxicity on liver, intestine and kidney in mice. Journal of Toxicology and Environmental Health Sciences. 2011;3(8):214-22.

30. Yun JW, You JR, Kim YS, Kim SH, Cho EY, Yoon JH, et al. In vitro and in vivo safety studies of cinnamon extract (Cinnamomum cassia) on general and genetic toxicology. Regulatory Toxicology and Pharmacology. 2018;95:115-23.

31. Han HY, Huh JI, Han SR, Kang MG, Yoon S, Han JS, et al. Assessing the safety of an Ephedrae Herba aqueous extract in rats: A repeat dose toxicity study. Regulatory Toxicology and Pharmacology. 2018;94:144-51.

32. Chen H, Sha X, Luo Y, Chen J, Li X, Wang J, et al. Acute and subacute toxicity evaluation of Houttuynia cordata ethanol extract and plasma metabolic profiling analysis in both male and female rats. Journal of Applied Toxicology. 2021;jat.4198. Available from: https://onlinelibrary.wiley.com/doi/10.1002/jat.4198

33. Kang C, Lee H, Hah DY, Heo JH, Kim CH, Kim E, et al. Protective effects of Houttuynia cordata Thunb. on gentamicin-induced oxidative stress and nephrotoxicity in rats. Toxicological Research. 2013;29(1):61-7.

34. Fowotade A, Fowotade A, Enaibe B, Avwioro G. Evaluating Toxicity Profile Of Garlic (Allium Sativum) On The Liver, Kidney And Heart Using Wistar Rat Model. International Journal Of Tropical Disease \& Health. 2017;26(2):1-12.

35. Hashemnia M, Rezaei F, Nikousefat Z, Bahiraei M. Toxicological evaluation of chronic oral administration of Melissa officinalis hydro-ethanol extract in SpragueDawley rats. Veterinary Science Development. 2017;7(1). Available from: https://www.pagepress.org/journals/index.php/vsd/article/view/6298

36. Secretariat A. e-Health Bulletin Towards Harmonisation of Traditional Medicine Practices ASEAN + 3 FETN : A Step Forward in. e-Health Bulletin. 2012;(2):1-8.

37. Sen S, Chakraborty R, De B. Challenges and opportunities in the advancement of herbal medicine: India's position and role in a global context. Journal of Herbal Medicine. 2011;1(3-4):67-75.

38. Peltzer K, Pengpid S. Prevalence and Determinants of Traditional, Complementary and Alternative Medicine Provider Use among Adults from 32 Countries. Chinese Journal of Integrative Medicine. 2018;24(8):584-90.

39. Peltzer K, Pengpid S. Utilization and practice of traditional/complementary/alternative medicine (T/CAM) in southeast asian nations(ASEAN) member states. Studies on Ethno-Medicine. 2015;9(2):209-18.

40. Widowati L, Nurhayati. The Use of Traditional Health Care Among Indonesian Family. Health Science Journal of Indonesia. 2017;8(1):30-5. Available from: http://ejournal.litbang.depkes.go.id/index.php/HSJl/article/download/5600/5238

41. Pengpid S, Peltzer K. Utilization of traditional and complementary medicine in Indonesia: Results of a national survey in 2014-15. Complementary Therapies in Clinical Practice. 2018;33:156-63.

42. Kalra A, Tuma F. Physiology, Liver [Internet]. StatPearls. StatPearls Publishing; 2018 [cited 2021 Jun 10]. Available from: http://www.ncbi.nlm.nih.gov/pubmed/30571059

43. Mishra S, Aeri V, Katare DP. Hepatoprotective medication for liver injury. World Journal of Pharmacy adn Pharmaceutical Sciences. 2014;3(5):891-932. 
44. Leise MD, Poterucha JJ, Talwalkar JA. Drug-Induced Liver Injury. Mayo Clinic Proceedings [Internet]. 2014;89(1):95-106. Available from: http://dx.doi.org/10.1016/j.mayocp.2013.09.016

45. Lin N, Yang $\mathrm{H}$, Su Y, Chang $\mathrm{C}$. Herb induced liver injury after using herbal medicine. 2018;

46. Amadi CN. An Update. 2018;(Dili).

47. Villanueva-Paz M, Morán L, López-Alcántara N, Freixo C, Andrade RJ, Lucena $\mathrm{MI}$, et al. Oxidative stress in drug-induced liver injury (Dili): From mechanisms to biomarkers for use in clinical practice. Antioxidants. 2021;10(3):1-35.

48. Suk KT, Kim DJ. Drug-induced liver injury: present and future. Clinical and molecular hepatology. 2012;18(3):249-57.

49. Roussel Uclaf Causality Assessment Method (RUCAM) in Drug Induced Liver Injury. LiverTox: Clinical and Research Information on Drug-Induced Liver Injury [Internet]. 2019 May 4 [cited 2021 Jul 25]; Available from: https://www.ncbi.nlm.nih.gov/books/NBK548272/

50. Danan G, Teschke R. RUCAM in Drug and Herb Induced Liver Injury: The Update. International Journal of Molecular Sciences 2016, Vol 17, Page 14. 2015;17(1):14. Available from: https://www.mdpi.com/1422-0067/17/1/14/htm

51. Barnett LMA, Cummings BS. Nephrotoxicity and renal pathophysiology: A contemporary perspective. Toxicological Sciences. 2018;164(2):379-90.

52. Skinner R. Nephrotoxicity - What do we know and what don't we know? Journal of Pediatric Hematology/Oncology. 2011;33(2):128-34.

53. Dhodi DK, Bhagat SB, Pathak D, Pathel SB. Drug-induced nephrotoxicity. International Journal of Basic \& Clinical Pharmacology. 2014;3(4). Available from: doi: 10.5455/2319-2003.ijbcp20140826

54. Vormann MK, Gijzen L, Hutter S, Boot L, Nicolas A, van den Heuvel A, et al. Nephrotoxicity and Kidney Transport Assessment on 3D Perfused Proximal Tubules. AAPS Journal. 2018;20(5):1-11.

55. Zarjou A, Agarwal A. Sepsis and acute kidney injury. Journal of the American Society of Nephrology. 2011;22(6):999-1006.

56. Pelkonen O, Duez P, Vuorela PM, Vuorela H. Toxicology of herbal products. Toxicology of Herbal Products. 2017. 1-479.

57. Anger EE, Yu F, Li J. Molecular Sciences Aristolochic Acid-Induced Nephrotoxicity: Molecular Mechanisms and Potential Protective Approaches. 2020; Available from: www.mdpi.com/journal/ijms

58. Dickman KG, Sweet DH, Bonala R, Ray T, Wu A. Physiological and molecular characterization of aristolochic acid transport by the kidney. Journal of Pharmacology and Experimental Therapeutics. 2011;338(2):588-97. Available from: https://jpet.aspetjournals.org/content/338/2/588

59. Kiliś-Pstrusińska K, Wiela-Hojeńska A. Nephrotoxicity of herbal products in europe-a review of an underestimated problem of nephrotoxicity of herbal products. International Journal of Molecular Sciences. 2021;22(8).

60. Zhu S, Wang Y, Jin J, Guan C, Li M, Xi C, et al. Endoplasmic reticulum stress mediates aristolochic acid I-induced apoptosis in human renal proximal tubular epithelial cells. Toxicology in Vitro. 2012;26(5):663-71. Available from: http://dx.doi.org/10.1016/j.tiv.2012.03.005

61. Xu X, Zhu R, Ying J, Zhao M, Wu X, Cao G, et al. Nephrotoxicity of Herbal Medicine and Its Prevention. Vol. 11, Frontiers in Pharmacology. Frontiers Media S.A.; 2020.

62. Umayah Ulfa E, Rachmawati E.. Artikel Penelitian Global Medical And Health Communication Uji Toksisitas Subkronik Ekstrak Kayu Kuning (Arcangelisia Flava 
Merr) Terhadap Hepar Dan Ginjal. Global Medical And Health Communication. 2018;6(1):1-6. Available from: http://ejournal.unisba.ac.id/index.php/gmhc

63. Kaplowitz N, DeLeve LD. Drug-Induced Liver Disease. Drug-Induced Liver Disease. Elsevier Inc.; 2013.

64. Calitz C, Plessis L du, Gouws C, Steyn D, Steenekamp J, Muller C, et al. Herbal hepatotoxicity: current status, examples, and challenges. http://dx.doi.org/101517/1742525520151064110. 2015;11(10):1551-65. Available https://www.tandfonline.com/doi/abs/10.1517/17425255.2015.1064110

65. Teschke R, Frenzel C, Glass X, Schulze J, Eickhoff A. Herbal hepatotoxicity: A critical review. British Journal of Clinical Pharmacology. 2013 Mar;75(3):630-6.

66. Locke AB, Kirst N, Shultz CG. Diagnosis and Management of Generalized Anxiety Disorder and Panic Disorder in Adults [Internet]. Vol. 91, American Family Physician. 2015 May [cited 2021 Jun 12]. Available from: www.aafp.org/afpAmericanFamilyPhysician617

67. Worland T, Chin KL, Rodrigues B, Nicoll A. A Retrospective Case-Controlled Cohort Study Of Inpatient Drug Induced Liver Injury: The RIDDLE Study. Translational Gastroenterology And Hepatology [Internet]. 2020 Jul 5 [Cited 2021 Jun 12];5. Available From: /Pmc/Articles/PMC7063506/

68. Gerussi A, Natalini A, Antonangeli F, Mancuso C, Agostinetto E, Barisani D, et al. Immune-mediated drug-induced liver injury: Immunogenetics and experimental models [Internet]. Vol. 22, International Journal of Molecular Sciences. MDPI AG; 2021 [cited 2021 Jun 12]. p. 4557. Available from: https://doi.org/10.3390/ijms22094557

69. Ekor M, Pistelli L. The growing use of herbal medicines: issues relating to adverse reactions and challenges in monitoring safety. 2014; Available from: www.frontiersin.org

70. Pillai PG, Suresh P, Mishra G, Annapurna M. Evaluation of the acute and sub acute toxicity of the methanolic leaf extract of Plectranthus amboinicus (Lour) Spreng in Balb C mice. European Journal of Experimental Biology. 2011;1(3):236-45. Available from: http://www.imedpub.com/articles/evaluationof-the-acute-and-sub-acute-toxicity-of-the-methanolic-leafextract-ofiplectranthus-amboinicusi-lour-spreng-in-balb-c-mi.pdf

71. Paniagua AC, Amariles P. Hepatotoxicity by Drugs. In: Pharmacokinetics and Adverse Effects of Drugs - Mechanisms and Risks Factors [Internet]. InTech; 2018 [cited 2021 Jun 12]. Available from: http://dx.doi.org/10.5772/intechopen.72005

72. Sari A. Nephrotoxic Effects of Drugs. In: Poisoning in the Modern World - New Tricks for an Old Dog? [Internet]. IntechOpen; 2019 [cited 2021 Jun 12]. Available from: www.intechopen.com 